\title{
The Implementation of the Brute Force Algorithm in the Design of Android-Based Thesis Catalog
}

\author{
Rahmi Tirajana Hasibuan ${ }^{1 *}$, Supratman Zakir ${ }^{2}$
}

1,2 Informatics and Computer Engineering Education IAIN Bukittinggi, Bukittinggi, Indonesia

\begin{tabular}{l} 
Article Information \\
\hline Article History: \\
Accepted by the Editor: November 24, 2021 \\
Final Revision: December 30, 2021 \\
Published Online: December 31, 2021 \\
Keywords \\
\hline Catalog \\
Thesis \\
Android \\
R\&D \\
ADDIE \\
Waterfall
\end{tabular}

\section{Correspondence}

\section{A B $\quad \boldsymbol{S}$ T $\mathbf{R}$ A $\mathbf{C}$ T}

The background of this research was there were a lot of students who were confused to find references for the title of their final project as college students due to several obstacles, one of which was the lack of information about the titles of theses that have been conducted at their campus. The thesis catalog that was used in the library of South Tapanuli Institute of Education (IPTS/Institut Pendidikan Tapanuli Selatan) still used printed media in one document in each department. It caused students must take turns reading the catalog or students can directly search for one-on-one thesis from the self of theses and the ongoing system has not used the database so as to probably allow the loss of alumni thesis title data recap. This was the reason why the authors designed a Thesis Catalog System by implementing the brute force algorithm in the process of searching for the titles of theses. This thesis catalog system was a system that aimed to facilitate the performance of library staff and employees in data entry, especially making it easier for students to find title references. This research method belonged to Research and Development which was a Development Research Method with an Analyze-Design-Develop-Implement-Evaluate model abbreviated as ADDIE. The development model was adopted from SDLC (System Development Life Cycle) with Waterfall method. The programming language used was PHP with database management system, namely MySQL. Based on the results of the research that the authors conducted, the result of the validity test obtained a value of 0.80 which was declared valid while the value for the practicality test was 0.889 with very practical criteria. For the effectiveness test, the value obtained was 0.871 with very effective criteria so that the value obtained proved that the thesis catalog system can be helpful and ready to be used. 


\section{Introduction}

In recent years, the paradigm of society in searching for and obtaining information that is no longer limited to place, time, and even distance. It has changed along with the development of information technology that is developing very rapidly. Information technology can be interpreted as a study, design and development, implementation and management of a computer-based information system. Information technology in obtaining information securely has utilized electronic computers and computer software to change, store, protect, process, and store data. [1]

Library has been affected by the rapid development of information technology today. Library as information management institution has implemented evolving information technology rapidly. The development of the implementation of information technology in library can be seen from the development of library types that are always related to information technology, starting from manual library, automated library, digital library or cyber library. [2]

Library is an institution that provides various references and collections of information sources with the aim of providing a place for the development of science for students, lecturers, researchers, and academics. [3] In addition, library also aims to provide services to library users so that prima facie library service activities become one of the elements that must be fulfilled. The service of a library can be said to be excellent if library users are satisfied with the service that runs in the library. Library is required to provide faster and more accurate information along with the development of technology. This activity must be carried out so that the existence of library in the era of information technology can be maintained amid the rise of other more sophisticated information provision.

The existence of libraries must also pay attention to the element of ease of access for users. Among the tools that can be used by users in facilitating access in the library are catalogues. Through the library catalog, users easily access the location of a destination in the library. In library catalog data lookup, there is a lookup process called string or known as string searching. Catalog data generated during string matching is highly dependent on the technique or algorithm used.

String matching is an important part of the string searching process in a document. The technique or way of string matching used is very influential on the result of searching a string in the document. The string matching process is the main part and plays an important role in obtaining documents that match the information needs. Consequently, it needs a good string searching method to find out the correct document content according to the information needs.

String Matching is one of several algorithms used to speed up the process of searching for the desired word. There are two types of String matching, namely exact matching and heuristic matching or statistical matching. String matching algorithm which is often used in the string matching process based on the data text equation namely Brute Force algorithm. The brute force algorithm is an algorithm to match pattern with all text between 0 and $n-m$ to find the presence of pattern in the text. This algorithm is classified as an algorithm that reads string from left to right when viewed based on its search direction. [4] 
This study implemented the Brute Force algorithm in hybrid application. The hybrid application is a programming development based on website with support of Database Management System namely $M y S Q L$ which is then transformed into the form of native code. This type of application can be used on android platform. This type of Hybrid application uses webview control which has function to represent HTML and Javascript files with the full-screen format.

Currently, the Faculty of Mathematics and Science Education at South Tapanuli Institute of Education (IPTS/ Institut Pendidikan Tapanuli Selatan) has a considerable number of Thesis collections. IPTS Library is a library located in the campus area of the Faculty of Mathematics and Science Education. At present, the library has not used library management software in managing its thesis collections.

This could lead to impractical entry of thesis data as well as the process of searching for thesis titles as the thesis guideline for students. For visitors and library members who wanted to read a thesis with a certain title, it took a long time to find the desired title because they must check whether the title listed has been done by other students or has never been done at all. Another problem that occurred was that the number of Theses that entered the library continued to increase. It caused the Theses title book collection to become more and more difficult to manage. Based on the problems that the authors found in the library of South Tapanuli Institute of Education (IPTS), the authors were interested in conducting a research and providing solutions to the problems in the library. By using a computerized system, it could help to facilitate the work of several parties including library staff, lecturers, and students more efficiently to find references.

\section{Methodology}

\subsection{R\&D Method}

The research method used belonged to the method of Research and Development $(R n D)$ which is the research used to produce a product and test the effectiveness of the product. [5] This study aimed to design a product in the form of a thesis catalog by implementing the brute force algorithm which would be implemented in a library unit of South Tapanuli Institute of Education (IPTS). In this study, the Research and Development (R\&D) method used was ADDIE version. This ADDIE model uses 5 phases of development, namely analyze, design, develop, implement, and evaluate.

The reason of the selection of ADDIE model was that ADDIE development model was relatively full of logic and principles of system approach and positivistic paradigm. Consequently, developing educational technology products would also follow the logic and principles of system approach and positivistic paradigm. [6] These five phases are very simple when compared to other design models. The following are the phases of ADDIE illustrated in figure 1 below:

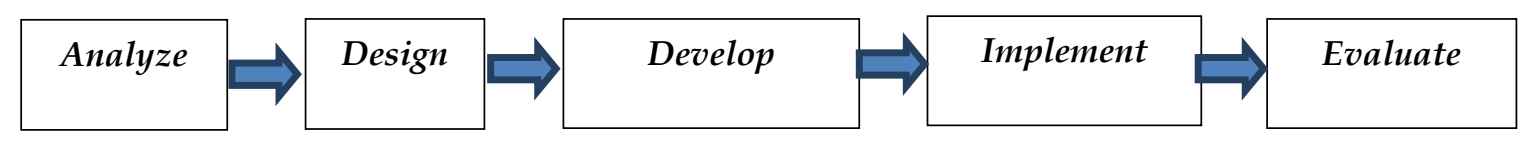

Figure 1. Phases of ADDIE Development Model

a. Analysis Phase

Analysis phase consists of defining what is needed, analyzing the situation, and identifying the problems.

b. Design Phase 
Design phase consists of making a design of the system that will be developed based on the results of the analysis.

c. Development Phase

Development phase is a series of processes to actualize the system that has been designed.

d. Implementation Phase

Implementation phase is a real form of implementing the system that is being created. This means that the system that has been generated will then be tested by several validators as people who are experts in their field.

e. Evaluation Phase

Evaluation phase aims to see if the product resulting from the designed system matches the expected one. This phase also contains improvements to the designed system based on advice and input from experts on the system product test questionnaire instrument.

\subsection{System Development Life Cycle (SDLC)}

This study used a system development model known as System Development Life Cycle (SDLC). According to Sukamto and Shalahuddin, System Development Life Cycle is the process of developing a software system by using several models and methodologies used to develop the previous software system based on several well-tested methods. [7]

SDLC has a function to describe several main phases and the phases are divided into five main activities, namely: analysis, design, implementation, testing, and maintenance. In this study, the Waterfall model was selected as the model for the development phases of the system. The SDLC development model is linear from the beginning phase of system development which is planning phase to the final phase which is maintenance phase. Waterfall model has iteration which means that the next phase will not be carried out before the previous one is completed and cannot go back or repeat the previous one.

Waterfall model has several phases in sequence, namely: communication (analyzing problems), planning (planning the system), modeling, construction (testing), and deployment (implementation).

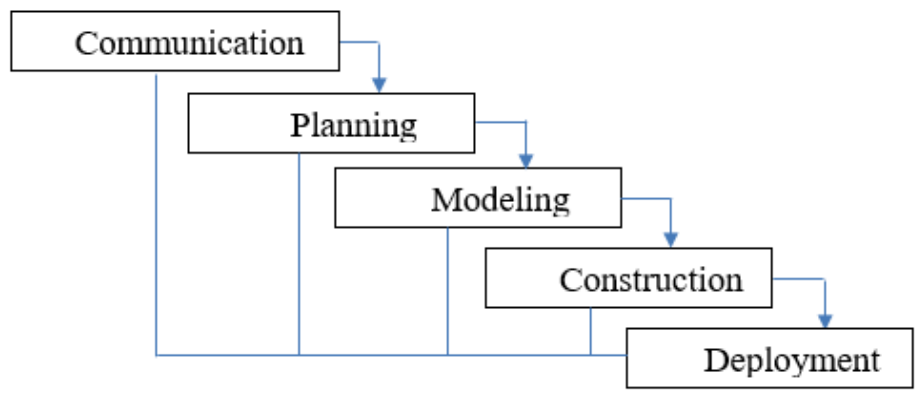

Figure 2. Phases of Waterfall Model

The following are the phases of waterfall model:

1. Communication Phase

The first step is the communication with costumer in order to be able to understand and achieve the goals that have been set before starting the work technically.

2. Planning Phase

The next stage is to establish a plan for the creation of software which includes the technical tasks to be carried out, the estimation of possible risks, the resources needed, the results to be made, the work schedule, and process tracking of working on the system.

3. Modeling Phase 
Modeling is a phase that includes the design and modeling of system architecture that focuses on the design of data structures, software architecture, display interface, and algorithm program. This modeling aims to better understand the general picture to be made.

4. Construction Phase

This phase is the process of translating design form into the programming language used. Coding is the translation of a design in a language that can be recognized by a computer. The purpose of construction is to find possible errors to be corrected later.

5. Deployment Phase

Deployment phase consists of the software implementation, periodic software maintenance and repair, software evaluation, and software development based on feedback given to the system so that it can continue to run and develop in accordance with its function.

\subsection{Product Test Formula}

a. Product Validity Test

To produce a quality product, it was necessary to have a product validity test. Validity test was carried out using a questionnaire instrument addressed to experts. The instrument of product validity test questionnaire consisted of several aspects, which were derived again into several assessment items. Experts then filled out each assessment item and then the results obtained from experts were processed by referring to Aiken Validity Formula with the following equation formula. [8]

$$
V=\sum \mathrm{s} /[\mathrm{n}(\mathrm{c}-1)] \quad \text { [Aiken's V] }
$$

Description of the formula:

The $\mathrm{s}$ value is obtained from: $\mathrm{r}-\mathrm{lo}$, where lo is the lowest validity assessment number, $\mathrm{c}$ is the highest validity assessment number. While $r$ is the number given by an assessor and $n$ is the number of assessors.

Determination of validity referred to the Aiken's V formula which was grouped in categories as follows:

Table 1 Criteria for determining the validity of Aiken's $\mathrm{V}$

\begin{tabular}{ll}
\hline \multicolumn{1}{c}{ V values obtained } & \multicolumn{1}{c}{ Category } \\
\hline $\mathrm{V}<0.6$ & Invalid \\
\hline $\mathrm{V}>=0.6$ & Valid \\
\hline
\end{tabular}

b. Product Practicality Test

Practicality test was also carried out using questionnaire instrument the same as validity test, but the difference was that practicality test instrument was aimed at practitioners in accordance with the field and topic of this research. Questionnaires that had been filled in by the practitioners were then collected and processed with reference to Kappa Moment Statistical Formula, with the following formula:

$$
k=\frac{\rho-\rho e}{1-\rho e}
$$

Description of the formula:

$k$ is the value of moment kappa which shows the practicality of the product. Meanwhile, $\rho$ is the realized proposal calculated by considering the number of values obtained by the examiners as the maximum number of values. Next, pe which is the unrealized proportion is 
calculated by calculating the number of maximum values minus the number of total values given by the examiners, divided by the number of maximum values.

Table 2. Result Categories Based on Moment Kappa (k)

\begin{tabular}{cc}
\hline Interval & Category \\
\hline $0.81-1.00$ & Very High \\
\hline $0.61-0.80$ & High \\
\hline $0.41-0.60$ & Moderate \\
\hline $0.21-0.40$ & Low \\
\hline $0.01-0.20$ & Very low \\
\hline$\leq 0.00$ & Impractical \\
\hline
\end{tabular}

c. Product Effectiveness Test

The product effectiveness test was the third product test in this study. Effectiveness test also used questionnaire instrument the same as validity and practicality tests, but was aimed at respondents, namely students. The results obtained from each assessment item filled in by the students in the effectiveness test questionnaire were then examined and processed by referring to Richard R. Hake statistical formula or known as G-Score formula as follows:

$$
<g>=\frac{(\%<s f>-\%<s i>)}{(100-\%<s i>)}
$$

Description of the formula:

$<\mathrm{g}>$ is the value of G-Score, where $<\mathrm{Sf}>$ is the final Score and $<\mathrm{Si}>0699$ is the initial Score.

The effectiveness criteria in the G-score formula are divided into several criteria as follows [20] : "High-g" means high effectiveness if the obtained g-score is $>0.7$. "Medium-g" means moderate effectiveness if $g$-score is $0.7>(<\mathrm{g}>)>0.3$, and it is said "Low-g" (low effectiveness) if $g$-score obtained is $<0.3$.

\section{Results and Discussion}

\section{Research Results}

This research produced a product, namely a thesis catalog system by implementing Android-based brute force algorithm which had gone through several phases as follows:

\section{Analyze}

Analysis was the first phase that the authors performed to create a system. This analysis aimed to find out the thesis catalog system in IPTS Padangsidimpuan. The analysis process was carried out by directly observing the ongoing system. In addition, by analyzing this system, it could be seen the problems and weaknesses found in the ongoing thesis catalog. Then improvements could be made to the new system that would be designed. The benefits of this thesis catalog are as an aid to data storage and to make it easier for students to find references for their final projects.

\section{Design}

In this phase, the authors described the design of the application based on the needs of users and systems, and also addressed to whom this application was made. In this phase, the authors designed a thesis catalog system in accordance with the needs of library at South Tapanuli Institute of Education, which was designed as follows: 
Admin flowchart system design. Admin flowchart systems are the steps for the admin start from login to logout. On this flowchart, admin logs in using username and password which have been set up for admin. If the input of username and password is correct, the admin can log in to access home, manage users on the application, manage data, and exit the application. On the manage-account page, the admin can add, change, and also delete thesis data. An overview of the admin flowchart system design is illustrated in figure 3 :

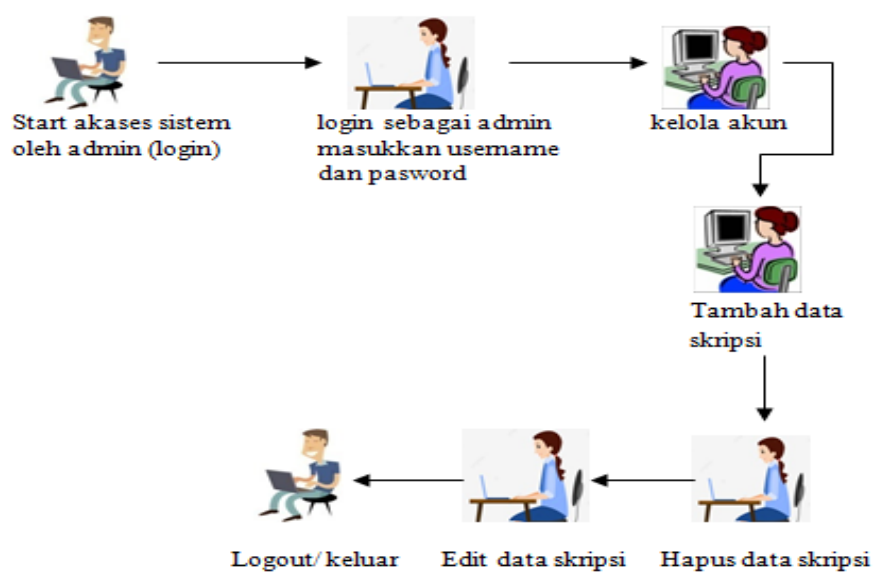

Figure 3. Admin Flowchart System Design

Lecturer flowchart system design. Lecturer flowchart systems are the steps done by the lecturers start from login to logout. On flowchart, the lecturers must login by using username and password correctly based on the access rights provided. If the username and password are correct, the lectures will enter home menu. Then, the lecturers can search for thesis data. If the username and password are wrong, the lectures will return to login menu. Lecturer flowchart system design is illustrated as in figure 4:

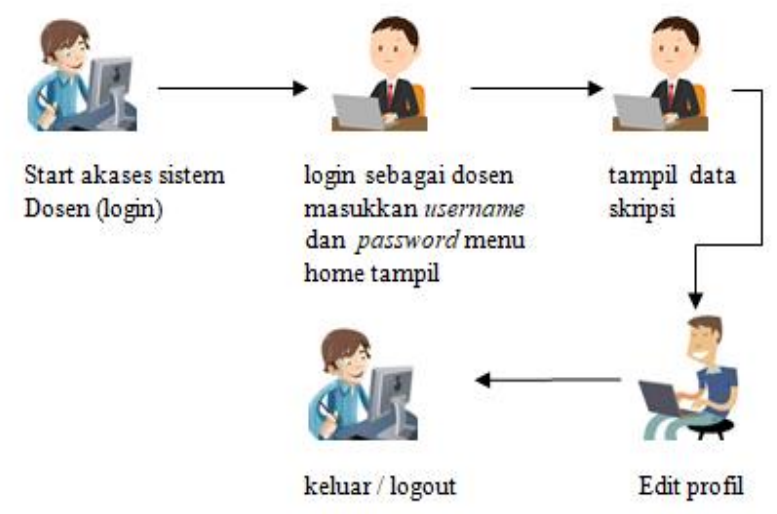

Figure 4. Lecturer Flowchart System Design

Student flowchart system design. Student flowchart systems are the steps done by the students start from login to logout as users. On this flowchart, the students must login by using username and password which have been set up for them. If the input of username and password is correct, the students can log in to access home menu, and the display of thesis data inputted by admin. Then, the students can search for thesis data or references based on their needs. The design of the student flowchart system is illustrated as in figure 5: 


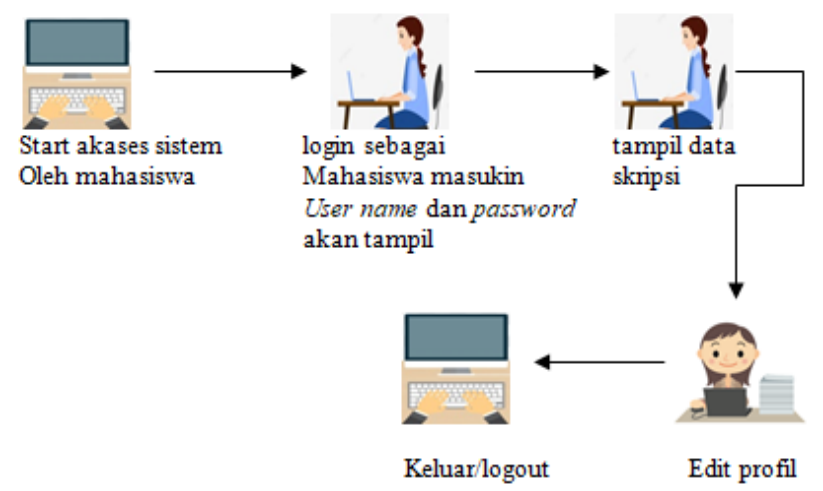

Figure 5. Student Flowchart System Design

\section{Development}

The development phase in this study referred to the phases of SDLC waterfall model, namely: communication, planning, modeling, construction, and deployment.

\section{Communication}

Before designing the system, the authors must know what data was needed, how the ongoing system was by gathering various information, and what were the obstacles experienced during using or working with the ongoing system. When the authors conducted an interview with IPTS library staff, there were several problems found, namely the lack of information related to accurate thesis titles and difficulties in searching for thesis books or title references for students' final project so that students needed more time to find titles for their final project reference materials. In addition, library staff inputted data into the software and printed thesis data for student reference of title search.

At this phase, there are several needs that are indispensable before performing the system design, namely: (1) Analysis of users' needs, including students who are users with the need for thesis title information and other related information. The next user is the admin who can manage the system as a whole starting from adding data, editing thesis data, and deleting thesis data. Other users are lecturers who search and get information about thesis data. (2) Analysis of system needs covers three things, namely functional needs, non-functional needs, and technological needs.

Functional needs. Functional needs should be able to describe the services the system can provide to users in detail. Functional needs in this system include the students can search for data thesis titles that are being inputted into the system, while the admin can input thesis data and can change or delete thesis data. The system can see the users who are logged into the system. Non-functional needs are the needs focused on the property needed by the system, namely the hardware needs consist of: Asus Intel (R) Laptop, Asus Intel (R) Laptop with Core(TM) i3-6006U, 2.0 GHz CPU, 4.00 GB RAM, and 64-bit Operating System. Software needs include: Windows 10, Sublime text 3 or visual code, PHP 5.6.1, MySQL database, XAMPP version 7.3, and Mozilla Firefox. Technological needs are needs that include equipment and also technological specifications to use this thesis catalog of data information system. As for the equipment and its specifications are: 1) Thesis catalog system: Android phone, computer, laptop with min 2 GB RAM, 2) Admin: Asus Intel (R) Laptop, Asus Intel (R) Laptop with Core(TM) i3-6006, 2.0GHz CPU, 2.00 GB RAM, and 64-bit Operating System. 


\section{Planning}

At this planning phase, the authors set out the plans that were carried out for the work on the system in which this system was worked on after the authors finished collecting information related to the thesis catalog. This planning began with the decisions that were made for the work of the system, namely the tasks that were in accordance with the procedure. The first step that the author did after doing communication with the system users was to start grouping the data based on the needs. After the necessary data was sufficient, the author started designing an overview of the android-based thesis catalog system in IPTS library with a schedule determined by the authors. At the time of designing this system, the authors discovered the risks that may occur when creating an application. Possible risks were damage and loss of some of the devices used, such as hardware and software devices. To prevent that from happening, the authors endeavored to always keep and check these devices periodically.

\section{Modeling}

This phase was the design and modeling phase of system architecture that focused on designing data structures, display interface software architecture, and algorithms program. The goal was to better understand the big picture of what to do. The modeling phase consists of: general system design and detailed system design.

1) System design in general. System design in general describes the application design globally starting from the design of usecase diagram, activity diagram, sequence diagram, and class diagram. Usecase diagram of IPTS thesis catalog application is illustrated in Figure 6, with the three actors consisting of administrators, lecturers, and students.

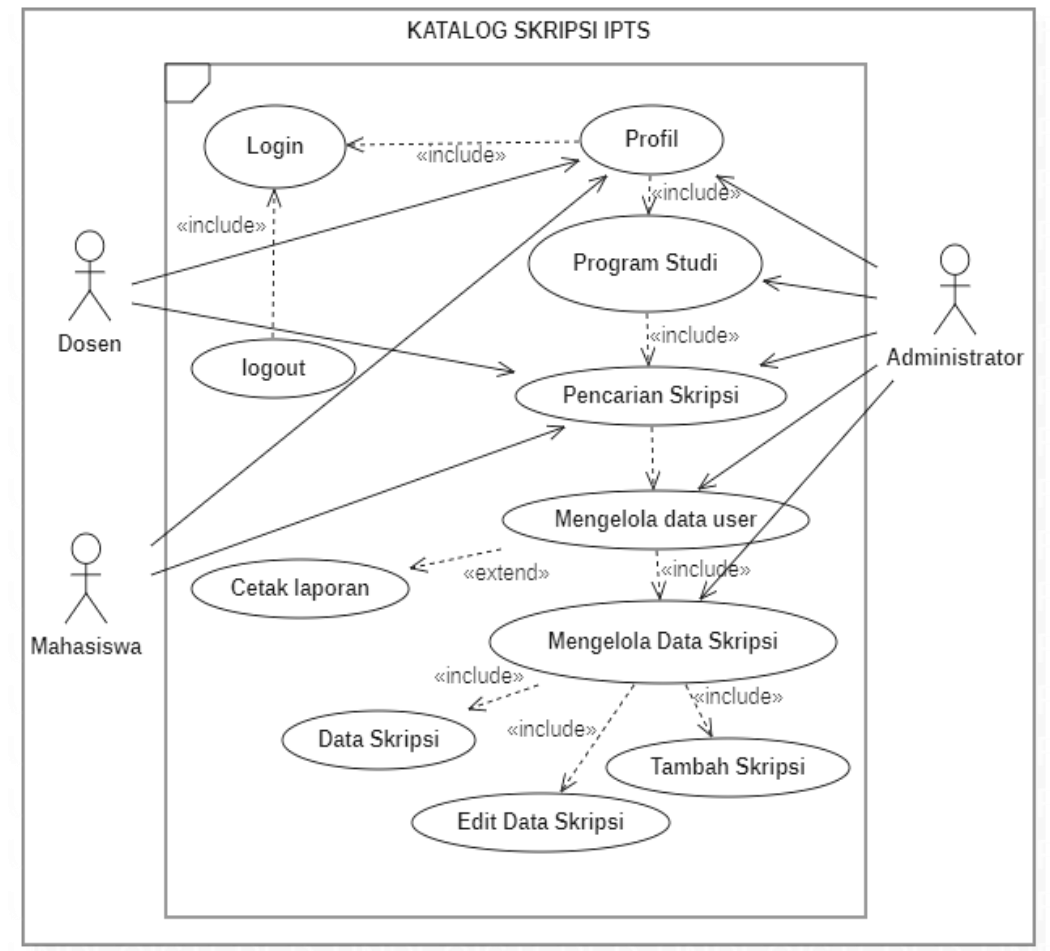

Figure 6. Design of usecase diagram of IPTS thesis catalog application

Activity diagram based on the usecase diagram in Figure 5 consists of three pieces, namely: administrator activity diagram, lecturer activity diagram, and student activity diagram. The design of activity diagram of IPTS thesis catalog application is illustrated in Figure 7: 

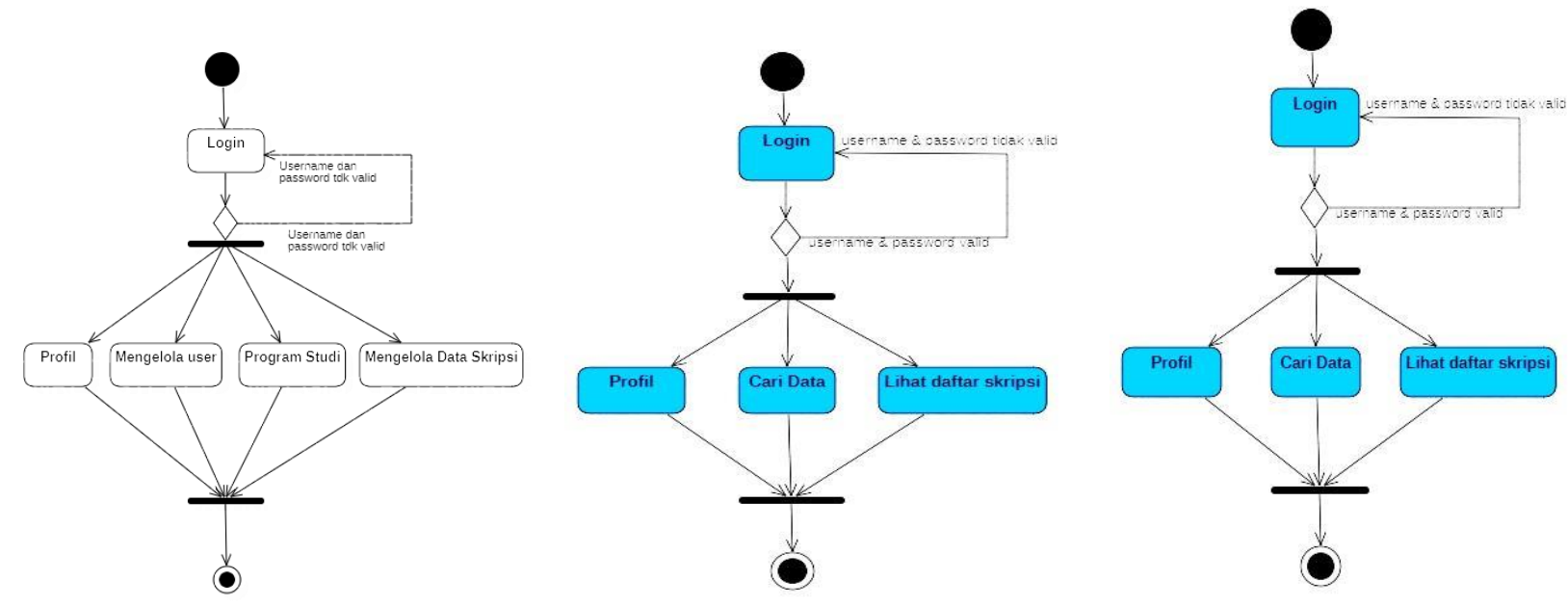

Figure 7. Design of activity diagram of IPTS thesis catalog application

Sequence diagram of IPTS thesis catalog application illustrates the data flow of each actor to the system. The design of sequence diagram of this application consists of three pieces, namely: sequence diagram of actors consisting of administrators, lecturers, and students as shown in Figure 8:
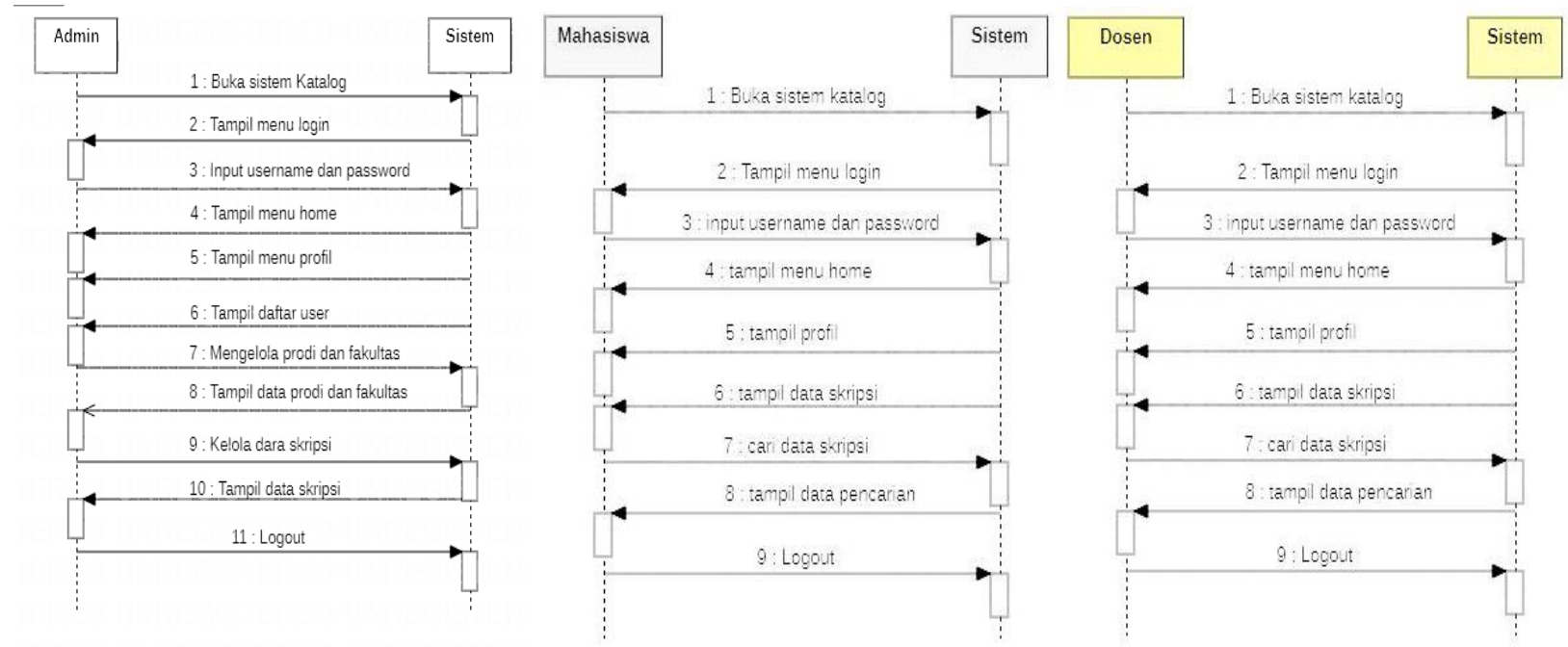

Figure 8. Design of sequence diagram of IPTS thesis catalog application

Class diagram. Database design of IPTS thesis catalog application is depicted as in figure 9. Class diagram essentially illustrates the relation of each table contained in the database. Moreover, class diagram also describes the attributes of each designed table. 


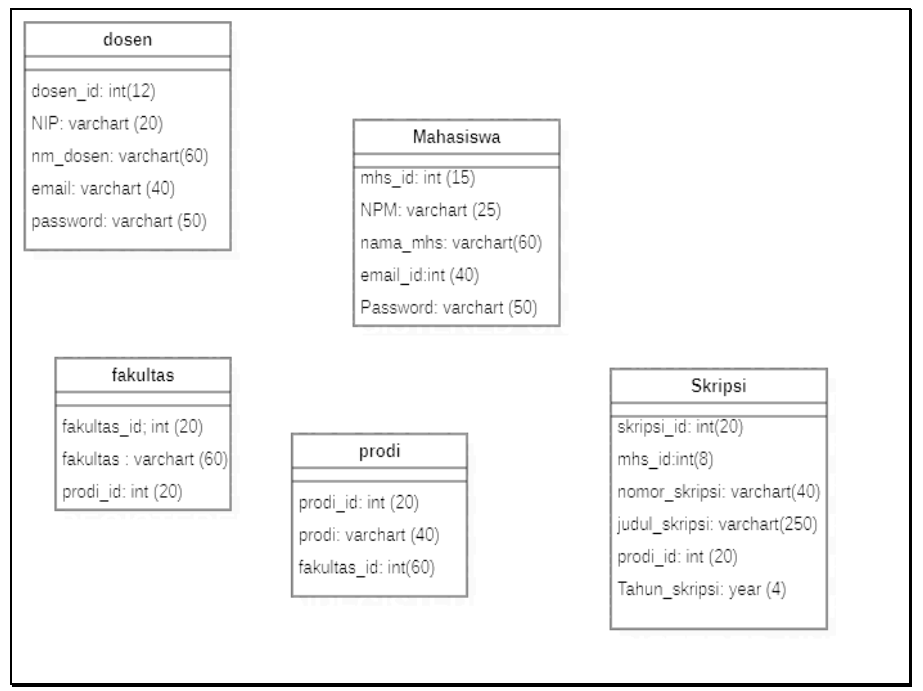

Figure 9. Design of class diagram of IPTS thesis catalog application

2) Detailed system design. Detailed system design in this study consists of: (1) Output system design consists of thesis data output design of all years, thesis data per-year, and thesis data by major; (2) Input system design consists of input design of students, lecturers, faculty, study program, and thesis. Database design consists of table design of students, lecturers, faculty, study program, and thesis.

\section{Construction}

This phase is a process of translating the design form into program code, a language that can be read by a machine. The goal is to see whether the design of the program is in accordance with planning, as an example of coding in this application as follows: Coding setup, this coding has function for setting of users' profile. The following is the deduction of setup code of this application.

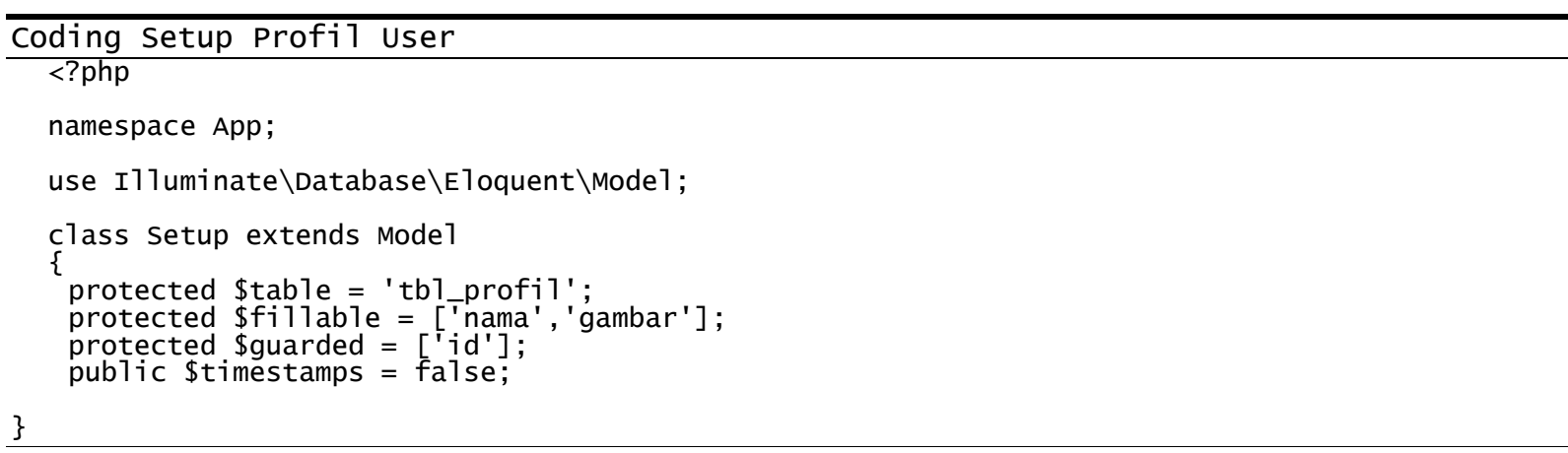

Coding user. This coding has function to add users' data in the administrator menu section. The following is the program code for adding users' data.

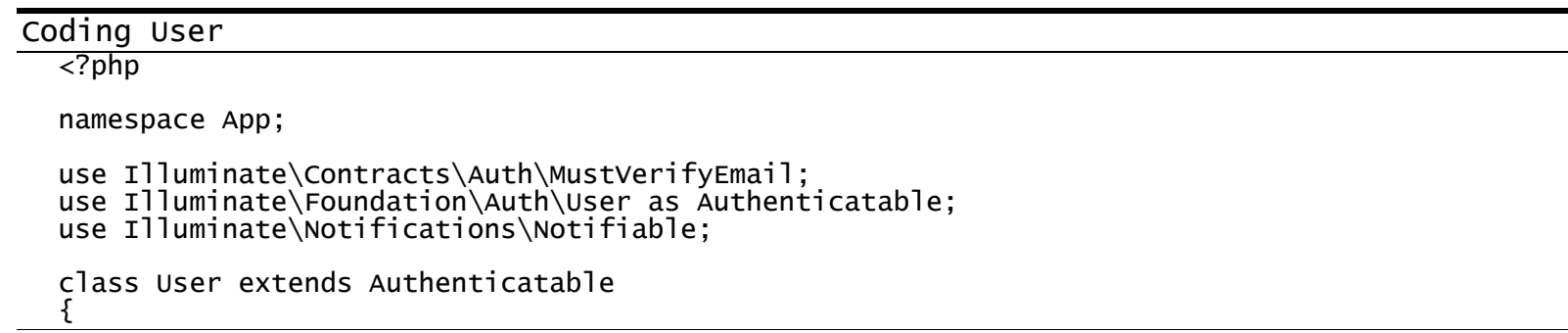




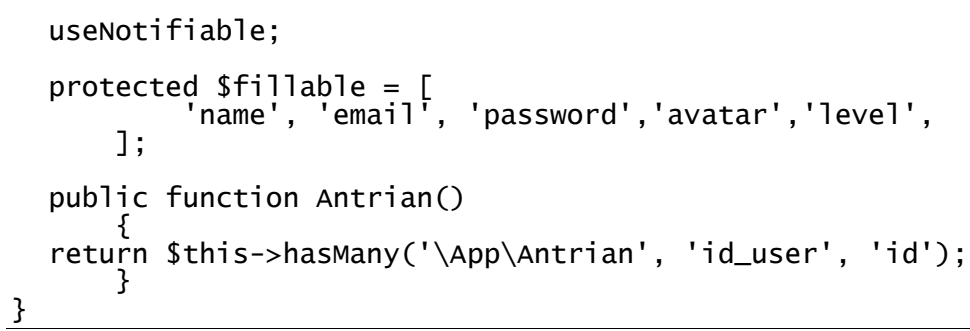

Coding study program (prodi). This coding has function to add study program data in the administrator menu. The following is the program code for adding study program data.

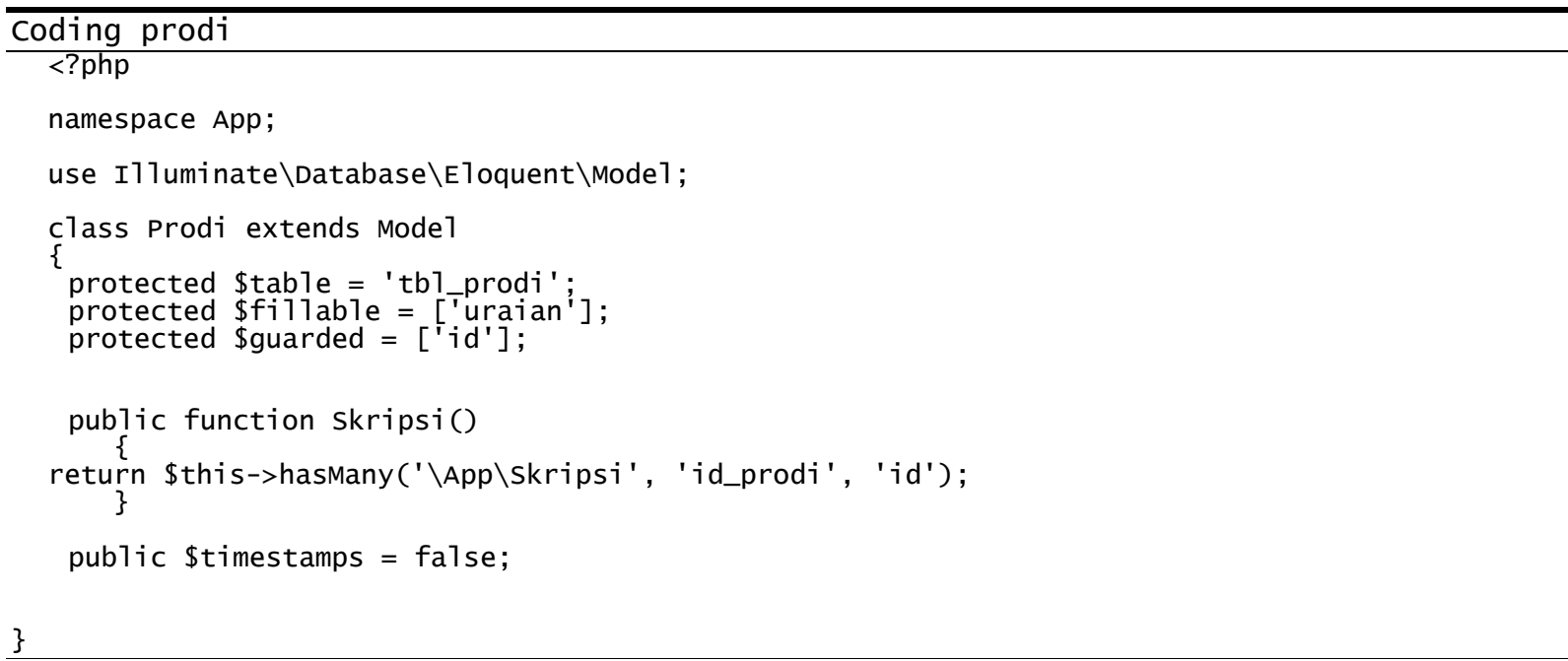

\section{Deployment}

The deployment phase is the trial stage that was conducted to users. The product trial method selected in this study was blackbox testing method. Blackbox testing method aimed to find out whether the system design was in accordance with the beginning plan or not. After conducting product trial with the blackbox testing method which consisted of testing each unit of the system and testing the system as a whole or integrated, it was found that the application of IPTS thesis catalogue in this study was in accordance with the initial design/the beginning plan and there was no error in the program. In addition, this system must also be maintained as gradually as possible. The purpose of this maintenance was to find out whether the program that had been designed was able to run properly or not. Therefore, to find out if the system had been successfully implemented, the implementation phase was carried out.

\section{Implementation}

The implementation phase was the real stage for implementing the planned system. The authors conducted a product trial which included product validity tests using a questionnaire instrument including 4 aspects, namely: program content, instructional design, appearance, and programming concepts. The validity test questionnaire instrument was aimed at 3 experts. The product validity test results obtained average value of 0.80 with a valid category.

Practicality test of the product used a questionnaire instrument consisting of 5 aspects, namely: the simple appearance of the product, the suitability of the applied writing composition and colors, the easiness of using product, the more practical presentation of the product contents, and repeated usage, and independent usage of the product without the help of others. The practicality test in the form of 
questionnaire instrument was aimed at two practitioners. Practicality test results tested using the kappa moment formula obtained a value of 0.89 with a very high practical category.

Effectiveness test of the product used a questionnaire instrument consisting of 5 aspects, namely easy in use, easy in accessing application, effective presentation of contents in the product, and repeated usage, independent usage of the product without the help of others. The questionnaire of product effectiveness test was aimed at 10 IPTS students, and then the assessment of questionnaire of the effectiveness test was processed using the $g$-score formula which obtained value of 0.87 with a very effective category.

\section{Evaluate}

The evaluation phase was a stage to see if the application ran well and as expected or not, and conducting maintenance towards the application. In this evaluation phase, the authors made improvements to the system or IPTS thesis catalogue application based on input or advice provided by experts and practitioners in the field. One of the suggestions was that the application needed to provide facility to download thesis abstracts and also facility to print thesis abstracts.

\section{Discussion}

This research has produced a product, namely an Android-based thesis catalog application with the implementation of the brute force algorithm. The research product has undergone product tests which included three things, namely product validity test by obtaining average value of 0.80 with a valid category, practicality test which resulted average value of 0.89 with a very high practical category, and product effectiveness test which showed a value of 0.87 with a high effectiveness category. Based on the product test results, it was stated that the product was feasible and were able to be further used or implemented.

In addition to the product test results obtained, in this study there were several inputs and suggestions from experts and practitioners in the field, namely that the application needed to provide facility to download thesis abstracts and also facility to print thesis abstracts. As the result of provided facilities, it will facilitate the users, especially students, in searching for sources and references in completing the final project.

The authors also conveyed some of the obstacles and shortcomings contained in this study so that it could be developed again by other researchers with the same theme. The obstacles or shortcomings in this study included: the resulting application was still classified as simple and in terms of data in the application did not cover all institutions, in addition, an estimate of the amount of data capacity in one institution had not been made so that it was not able to be calculated how much the total of database, and how much speed website must be accumulated in order for user to quickly access this application.

\section{Conclusion}

This research has produced a product namely an Android-based IPTS thesis catalog application with the implementation of the brute force algorithm. Based on product tests which included validity, practicality and effectiveness tests, it was stated that the product was feasible and could be further used or implemented. Although the product was declared feasible for use, there were several disadvantages, namely that the resulting application was still classified as simple and in terms of data on the application did not cover all institutions. An estimate of the total of database and the speed website had not been made. Some of the deficiencies presented in this article were intended to be further developed for other researchers who will also conduct research on the same topic as this article. 


\section{Referensi}

[1] T. N. Himmah and D. S. F. Azisi, "Pengaruh Perkembangan Teknologi Informasi Terhadap Layanan Perpustakaan Iain Tulungagung," BIBLIOTIKA J. Kaji. Perpust. dan Inf., vol. 3, no. 2, pp. 123-130, 2019, [Online]. Available: http://journal2.um.ac.id/index.php/bibliotika/article/view/11595.

[2] M. E. Apriyani and A. Dzikri, "Pemanfaatan Sistem Informasi Terintegrasi untuk Pengembangan Perpustakaan di Politeknik Negeri Batam," J. Integr., vol. 5, no. 1, pp. 91-95, 2013.

[3] R. Seyaningrum and Y. Mulyanto, "PENGEMBANGAN SISTEM INFORMASI PERPUSTAKAAN PADA UNIVERSITAS TEKNOLOGI SUMBAWA BERBASIS ANDROID," Sci. Technol., vol. 3, no. 2, pp. 26-37, 2019.

[4] M. Mesran, "Implementasi Algoritma Brute Force Dalam Pencarian Data Katalog Buku Perpustakaan," Maj. Ilm. INTI, vol. 3, no. 1, pp. 100-104, 2014.

[5] T. A. Farma and R. Okra, "Pengembangan Aplikasi Pembayaran dan Didukung oleh Pesan WA Sebagai Notifikasi Pembayaran di SMA INS Kayutanam," JSTIE (Jurnal Sarj. Tek. Inform., vol. 9, no. 1, 2021, doi: 10.12928/jstie.v1i1.17363.

[6] E. Subkhan, sejarah dan paradigma teknologi pendidikan untuk perubahan sosial. kencana: prenadamedia Group, 2014.

[7] A. N. Khomarudin and L. Efriyanti, "Pengembangan Media Pembelajaran Mobile Learning Berbasis Android Pada Mata Kuliah Kecerdasan Buatan," J. Educ. J. Educ. Stud., vol. 3, no. 1, p. 72, 2018, doi: 10.30983/educative.v3i1.543.

[8] R. A. Sundari and H. A. Musril, "Pengembangan Sistem Informasi Database Alumni ( Studi Kasus : SMAN 1 2x11 Enam Lingkung )," vol. 15, no. 2, pp. 115-124, 1858. 